\title{
A marótárcsás kotrógépek gémszerkezete maradék élettartamának meghatározása roncsolásmentes módszerrel
}

\section{Remaining lifetime assessment of bucket wheel excavator's boom structure by using non-destructive method}

\author{
András József, ${ }^{1}$ Kovács József, ${ }^{2}$ András Endre, ${ }^{3}$ Kertész Ildikó, ${ }^{4}$ Tomuș Ovidiu Bogdan ${ }^{5}$ \\ Petrozsényi Egyetem, Gépész- és Villamosmérnöki Kar, Gépész-, Ipari és Szállitásmérnöki Tanszék, \\ Petrozsény, Románia \\ 1 iosif.andras@gmail.com \\ ${ }^{2}$ kovacsi@mail.com \\ ${ }^{3}$ andrei.andras@gmail.com \\ ${ }^{4}$ kerteszildiko@ymail.com \\ ${ }^{5}$ tobogdan@gmail.com
}

\begin{abstract}
The bucket wheel excavators (BWE), when operating in faces with hard intrusions (rock structures with increased cutting resistance) are submitted to loads exceeding those arising during the operation in normal conditions. The most vulnerable structural element of the BWE from the point of view of these loads is the boom. The unexpected occurrence of hard formations produces shocks and vibrations, their unwanted effect being sudden failures of the constitutive elements and, in long term, fatigue, which increases the vulnerability of the mentioned structural element. In the paper we present the results obtained regarding the fatigue and remaining lifetime assessment using a new method, issued from the researches performed in the frame of BEWEXMIN project.
\end{abstract}

Keywords: bucket wheel excavator, fatigue, lifetime, surface hardness.

\section{Összefoglalás}

A marótárcsás kotrógépek a nehezen jöveszthető beágyazódásokat tartalmazó, külszíni fejtésekben üzemeltetésük során megnövelt igénybevételnek vannak kitéve, mely során meghaladják a normális körülmények között való működésnek megfelelő értékeket. A kotrógépek legnagyobb mértékben veszélyeztetett szerkezeti része az említett igénybevétel szempontjából a gém. A nehezen jöveszthető beágyazódások váratlan megjelenése sokkot és rezgést eredményez, melyek nem kívánatos hatása az alkotóelemek meghibásodása és hosszú távon azok fáradása, amely növeli a gém veszélyeztetettségét. Jelen munka, a kotrógép gémszerkezetének fáradását és annak maradék élettartamának meghatározását illetően, a BEWEXMIN projekt keretében folytatott kutatások eredményeit mutatja be.

Kulcsszavak: kotrógép, fáradás, élettartam, felületi keménység.

\section{Bevezetés}

A hosszú ideig ismétlődő terhelésnek kitett szerkezetek elemei felületi keménységmérési adatainak felhasználása mint a kifáradási állapot mutatója aránylag új eljárás a szerkezetek elemzésében.
E megközelítés tárgyát többnyire a fémből készült hidak, daruk, épületek tartószerkezete, tenger alatti fémszerkezetek, csővezetékek (amelyek főleg szeizmikus terheléseknek vannak kitéve) és más mechanikai alkatrészek, mint pl. a fogaskerekek képezik. 
A közelmúltban a nagyméretű földmunkagépek, mint például a marótárcsás kotrógépek tehertartó részegységei, szintén ennek a megközelítésnek lettek a tárgyai [1].

Kísérleti kutatások alapján megállapították, hogy az acél esetében a fáradás ellenállási együttható csökkenése összefüggésbe hozható a Brinellkeménység (HB) növekedésével.

Annak ellenére, hogy az úgynevezett ciklikus keményedéssel és lágyulással kapcsolatban a szakembereknek különböző véleményük van, az acélelemek képlékeny alakváltozásnak kitett zónáinak keményedését jelzi a szakirodalom. Daruk acélszerkezete maradék élettartamának meghatározását roncsolásmentes módszerrel [2] tárgyalja. Különböző bányagépalkatrészek maradék élettartamát keményedésvizsgálat alapján [3] mutatja be. Tenger alatti fémszerkezetek, csővezetékek kifáradását a keménység változása függvényében [4] tárgyalja, [5] pedig a fémhidak maradék élettartamának meghatározását keménységmérések segítségével tanulmányozza.

Több elméleti megközelítés eredményeit is publikálták, amelyek közvetve mutatják az összefüggést a keményedés és az ismétlődő terhelési ciklusok száma között.
Ilyen például az 1. ábrán szemléltetett, a kifáradási arány és a Brinell-keménység közötti meghatározott statisztikai korreláció [6].

A jelen dolgozatban tárgyalt keménységnövekedést, az ismétlődő terhelési ciklusok számának függvényében (ezeket a működési idő alapján határoztuk meg) úgy állapítottuk meg, hogy a kotrógép gémszerkezeti elemeinek kritikus pontjairól gyüjtött mintákon mért keménységnövekedést összehasonlítottuk az azonos márkájú, eredeti acélmintákkal, amelyeket törésig tartó húzófeszültséggel terheltük, mégpedig a törés közelében mért keményedéssel.

A keménység relatív növekedésének jelentős értéke arra a következtetésre vezetett, hogy a keménységet a fáradási szilárdság mutatójának lehet tekinteni, azaz hogy a vizsgált szerkezet hátralevő (maradék) élettartamának értékeléséhez alkalmazható.

\section{A vizsgált anyag és a vizsgálati mód- szer}

Vizsgálatunk háromtípusú mérést igényelt, az alábbiak szerint:

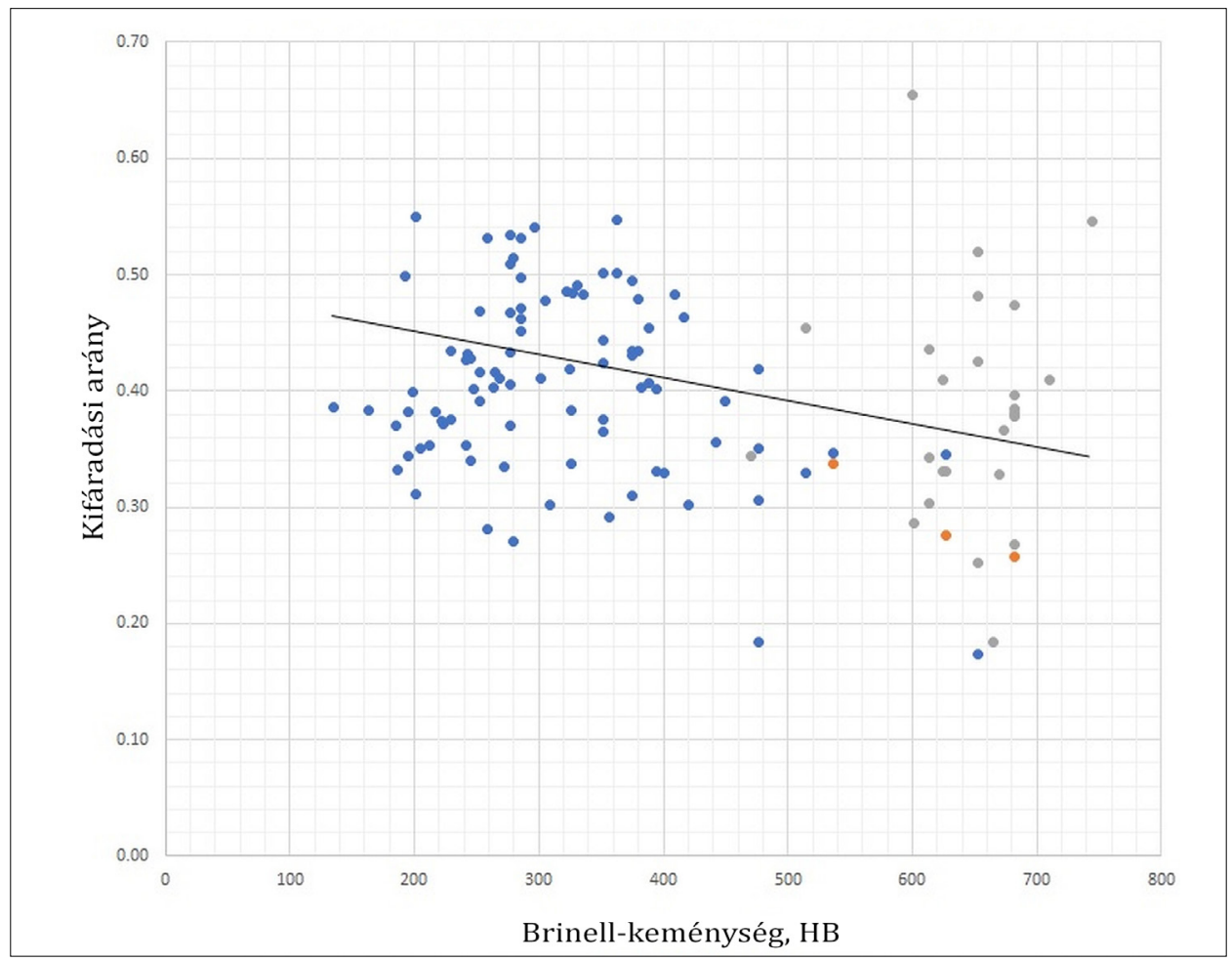

1. ábra. A Brinell-keménység növekedése a kifáradási arány csökkenésével [6] 
- együttes keménységi és szakítóvizsgálati mérések azonos típusú acélmintákon, amelyeket a kotrógép szerkezetének gyártásánál használtak, és amelyek kimutatták a felületi keménység növekedését a törés közelében, a minta sértetlen részének a keménységéhez viszonyítva;

- keménységi és szakítóvizsgálati mérések a kotrógép gémszerkezetének elemeiből készített mintákon, melyek az adott szerkezeti elem megújítása során, meghibásodás esetén helyettesítve lettek;

- keménységmérések in situ, a kotrógép gémszerkezetének kijelölt elemeiben, amelyeket végeselem-módszerrel végzett elemzés és a meghibásodási történet alapján választottunk ki, egy hordozható, roncsolásmentes vizsgálatot lehetővé tevő, Krautkramer MIC 20 keménységmérő készülékkel. Ezek eredményei a 2. ábrán láthatók.

A keménység mérését kiterjesztettük egy hét gépből álló, ERc1400-30/7 típusú kotrógépflottára az olténiai szénmedence különböző külszíni bányáiból, az azonos részegységre, ill. a gémszerkezetre vonatkozólag.

A 3. ábra a Brinell-keménység relatív növekedését mutatja, a 2. ábra pedig az átlagos keménység összefüggését az üzemeltetési idő függvényében, a különböző kotrógépek esetében, melyeknek gémszerkezeteiből mintadarabokat gyüjtöttünk.

Megfigyelhető, hogy az általános tendencia a keménység növekedése. Az utolsó mérési pont értéke eltérésének oka az, hogy egy esetben az alkalmazott acél más jellegű, mint a többi kotrógép esetében, az egyéb eltérések az átlagolásnak és a terhelési történetnek (azonos korú gépek esetében kevesebb üzemeltetési idő) tulajdoníthatók.

Mindamellett a gémszerkezet különböző elemeinek a keménysége közötti különbség hasznos információkkal szolgálhat a különböző szerkezeti

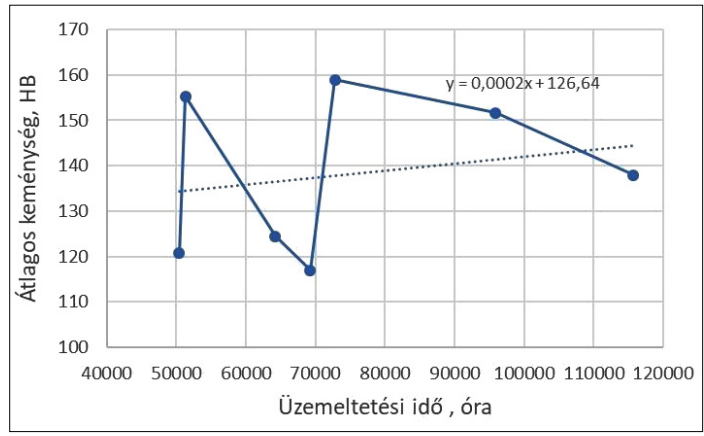

2. ábra. A kotrógépek gémszerkezeti elemein mért átlagos keménység a müködési idő szerint részek fáradásának mértékéről, főleg azok azonosítására, amelyek esetében a meghibásodás valószínűsége nagyobb.

Két ERc1400-30/7 típusú kotrógép gémszerkezetén, amelyek ugyanabban a bányában, hasonló feltételek között müködtek, keménységmérést végeztünk a gémszerkezet hosszán elhelyezett pontokban, a rácsos szerkezet hegesztett kapcsolatainak közelében.

Az adatok feldolgozása után kapott eredményeket a 4. ábrán szemléltetjük.

Az adatokból kitűnik, hogy a keménységi tulajdonságok közötti különbséget nem befolyásolja annyira a kotrógépek müködési ideje közötti különbség, mint a rácsszerkezet csomópontjain való elhelyezkedésé, ami az igénybevétel-különbség miatt szükségszerünek is mondható.

Ez a tény, más elemzésekkel összefüggésben, hasznos lehet egy komplex, multifaktoriális diszkrimináció-módszer kidolgozásában a gém leginkább veszélyeztetett részeinek az azonosítása érdekében.

\section{A kotrógépek életkorának hatása a meghibásodások gyakoriságára}

A marótárcsás kotrógépek teherbíró szerkezetein, a működési idő folytán különböző károsodások történhetnek, főleg a fáradási ellenállás csökkenése miatt.

A vizsgált 25 kotrógépen, amelyek több külszíni bányában működtek, meghibásodási térképezést végeztünk, illetve a gép vázlatrajzán kijelöltük a meghibásodás fajtáját a megfelelő szerkezeti elemen.

A meghibásodások számát, a gép életkorának függvényében és a működési idő, illetve a kitermelt meddő kőzet és lignit mennyiségét is számba véve, az 5. és a 6. ábrán mutatjuk be.

A meghibásodások száma és a keménységnö-

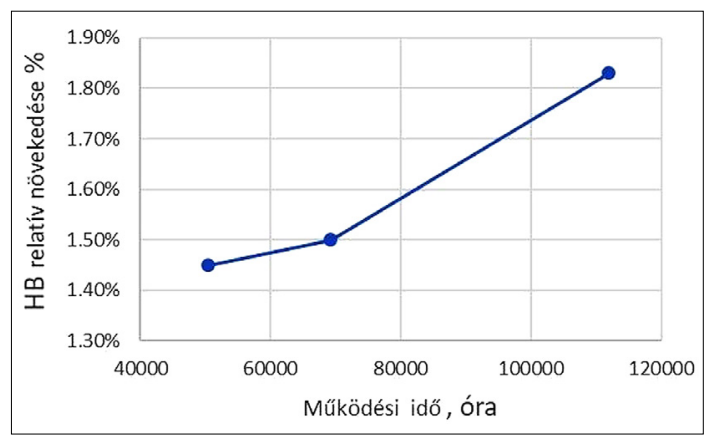

3. ábra. A Brinell-keménység relatív növekedése a vizsgált kotrógépek müködési időtartamának függvényében 

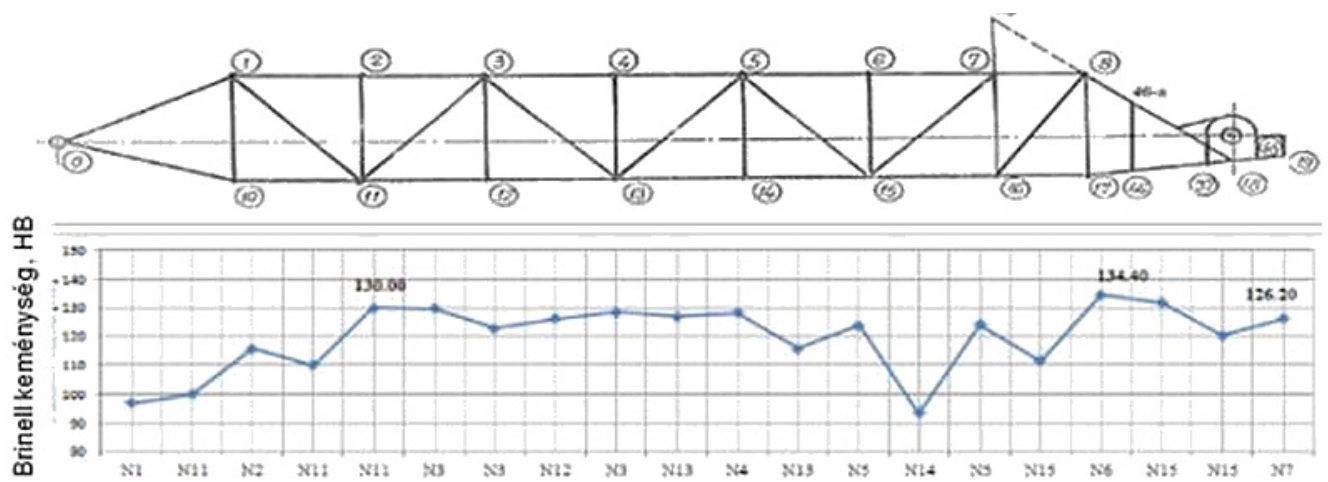

Csomópont szám

a)

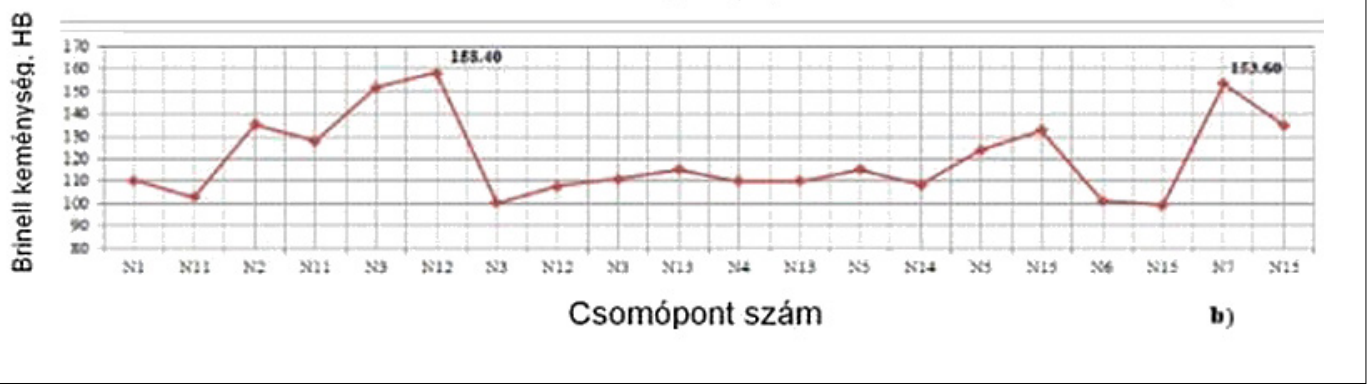

4. ábra. Két különböző kotrógép gémszerkezetén mért keménység eloszlása

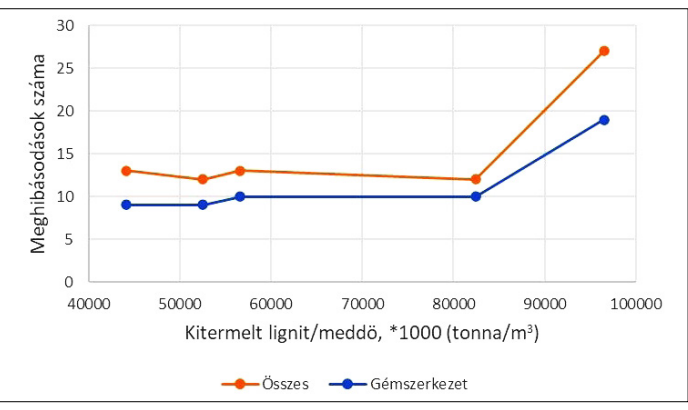

5. ábra. A meghibásodások száma, a gép által kitermelt lignit és meddőkőzet-mennyiség függvényében

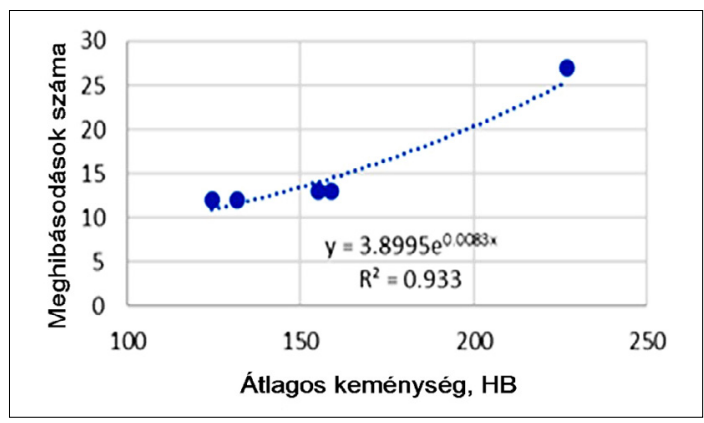

7. ábra. Összefüggés a meghibásodások száma és a keménység növekedése között

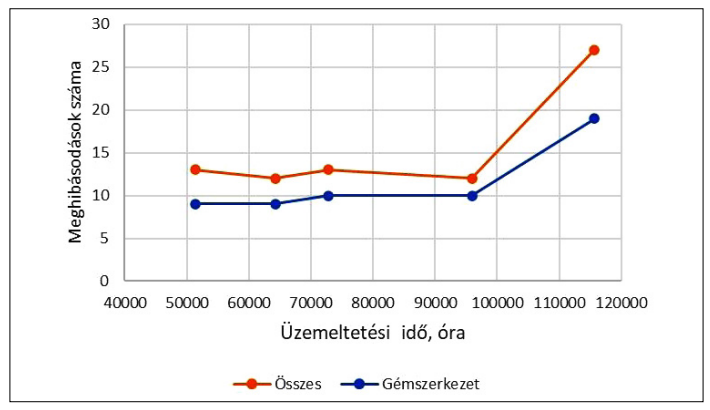

6. ábra. A meghibásodások száma a gép életkorának függvényében

vekedés közötti összefüggés segítségével előre lehet jelezni a meghibásodások valószínűségét a keménységmérésekre alapozva, a 7. ábra szerint.

\section{Következtetések}

A fémszerkezetek mechanikai tulajdonságai romlásának keménységmérésekre alapozott elemzése hasznos módszer lehet a bányagépek szerkezetei jellemzőinek vizsgálatában, és hasznos információkat nyújthat a gép teherhordó szerkezeti összetevőinek állapotáról és annak időben való változásáról. 
A keménység jelentős relatív növekedése a szolgálati időtartam függvényében arra a következtetésre juttat, hogy a keménységet a fáradási ellenállás mutatójának lehet tekinteni és a szerkezet hátralevő élettartamának értékeléséhez lehet alkalmazni.

Különböző összefüggéseket mutattunk be a meghibásodások gyakorisága, működési idő, termelékenység között, amelyek hasznos információt szolgáltathatnak a kotrógépek szerkezeteinek állapotelemzése számára.

A meghibásodási számnak a keménységnövekedéssel való korrelációja lehetőséget ad a várható meghibásodások előrejelzésére az átlagos keménységnövekedés ismerete alapján.

A keménységkülönbség a gémszerkezet különböző elemei között hasznos információval szolgál a különböző szerkezeti elemek kifáradási mértékének meghatározásához, valamint elősegíti az érzékelők elhelyezési pontjainak megállapítását.

Az eredmények, egyéb elemzésekből eredő információkkal összehangolva, egy komplex, multifaktoriális diszkriminációs módszer kidolgozásához vezethetnek a gémszerkezet legveszélyeztetettebb részeinek azonosítása céljából.

A módszer önmagában új lehetőséget nyújt a kotrógépek állapotának felmérésére és a fennmaradó élettartamának előrejelzésére.

\section{Szakirodalmi hivatkozások}

[1] Boskovic S., Jovancic P., Ignjatovic D. et al.: Vibration as deciding parameter during revitalization process for replacing the bucket wheel drive. Journal of Vibroengineering, 17/1. (2015) 24-32. https://www.jvejournals.com/article/15632

[2] Vîlceanu F., Radu S. M.: Methodology of establishing residual lifetime of lifting installation by non-destructive methods. $6^{\text {th }}$ International Multidisciplinary Scientific Symposium, Universitaria Simpro 2014, 10-11 october 2014, Petroşani.

[3] Zvonarev I. E., Ivanov S. L.: Analysis of changes in hardness of a metal surface layer in areas of high stress and methods of determining residual life of parts for mining machines. IOP Conf. Series: Materials Science and Engineering, 116. (2016) 012006

https://doi.org/10.1088/1757-899X/116/1/012006

[4] Drumonda G., Roudetb F. I.: High cycle fatigue damage evaluation of steel pipelines based on microhardness changes during cyclic loads. $23^{\mathrm{ème}}$ Congrès Français de Mécanique Lille, 28 Août au $1^{\text {er }}$ Septembre 2017.

[5] Chaminda S. Bandara, Sudath C. Siriwardane, Udaya I. Dissanayake and Ranjith Dissanayake: Hardness-Based Non-destructive Method for Developing Location Specific S-N Curves for Fatigue Life Evaluation. Journal of Civil Engineering and Architecture, 10. (2016) 183-191.

https://doi.org/10.17265/1934-7359/2016.02.007

[6] Hardness versus Fatigue Strength, August 8, 2017 by Steel Market Development Institute https://barfatigueblog.org/2017/08/08/hardness-versus-fatigue-strength/ (letöltve: 2019. május 15.). 